\title{
Literary Strange Attractors in Edith Wharton's The Age of Innocence
}

\author{
Janet Dawson \\ Universidad de Sevilla
}

Most reviewers and commentators mention irony as a notable feature of Edith Wharton's Age of Innocence (1920), but tend to dismiss it as a surface stylistic feature. In this paper, I use the 'chaotic' concept of strange attractors to show that the many clustered intertextual references in the novel, which correspond to books that the characters are reading or exposed to, may constitute a separate strand of irony alongside that overtly expressed by the unreliable narrator at the surface level. The question arises whether the two veins of irony are additive, that is, reinforce each other, or whether one counters the other. I believe that the result is indeterminacy, which militates against finding a single meaning or a single discursive function for the work and raises the question of the relationship between reader and text.

The critical literature has regarded The Age of Innocence variously as a historical evocation of Old New York in the 1870s; a sentimental, quasi-adulterous and star-crossed love story; Edith Wharton's fictional memoir; or the interactions between individual and society. The main problems with the text begin with the identity and location of the narrator. Although there is some dialogue between the characters in the fictional present, much of the narrative comes from the unidentified narrator placed in an unidentified time zone after the events it reports have taken place. The voice belongs to none of the characters. Usually, but not exclusively, Newland Archer, the hero, is the narrative focus and the narrator is particularly close to his thoughts and feelings. However we must finally discard him as being the definitive voice unless we consider him capable of performing impossible logical feats such as reporting simultaneously on his inability to think a particular thought in a particular situation and on what he would have thought, said or done if he had had the ability.

The tone of the narrator is heavily ironic and is marked in the text by inverted commas, parenthetical asides, and pragmatic mitigators, all of which conventionally draw attention to the gap between what is said and what the narrator wants us to think. Sometimes its chronological standpoint appears to be distant and with perfect hindsight. Sometimes the voice takes us so close to the feel of an experience that the reader is caught up within the mind of the thinking and feeling person, usually Newland, in the early 1870s. There is always already no single solution to what the narrator wants us to think. Martin Scorsese's film solution to the question of the identity of the narrator is to superimpose a female voice over the dramatic action. This implies that it belongs to Edith Wharton, the only female it could conceivably belong to, although it might also be an abstract composite of the female characters who, in the end, know Newland Archer better than he does himself. 
My research into chaotic paradigms, such as fractals, strange attractors and the butterfly effect, coincided with reading this novel and finding clusters of literary and cultural allusions which were difficult to place in a context. The incongruous fact emerged, after further research, that the literary figures had somehow been fictionally published ahead of time, and this in a novel which demonstrates its historicity in the opening lines, January of the early 1870s. The major production of Huysmans, Vernon Lee, Bourget and Guy de Maupassant, for example, was from the 1880s onwards. Strange attractors seemed to be a possible way to look at the relationship between hidden aspects of the intertext and the surface narrative. Does a reading achieved using the literary allusions as strange attractors reinforce or alter existing critical comment? Put another way, since Newland is the major consciousness, is our perception of him from the critical literature as a confused but sympathetic champion of women altered or reinforced by the construction that we build of him out of what he is, and is not, reading? Is, then, the novel really one of 'renunciation,' 'withdrawal' or 'nostalgia,' as the critics say?

In chaos theoretical physics and mathematics, strange attractors are representations of irregular and complex motions, such as turbulent air flows or flowing water and contrast with the regular periodic motions described by the pendulum in classical physics. ${ }^{1}$ To discover the shape of a dynamical system and its strange attractor(s), numerical data, expressed as a time series, are converted into pictures in the form of a phase portrait. The reconstruction works not only for a chaotic time series but for any time series, characterising the sequential variability occurring in each one. Although originally developed for talking about quantitative mathematical systems, non-quantifiable systems, such as texts, have similar enough properties for us to discuss them informally in similar terms. To quote Lass, the shape of historical developments can be discussed in an expository language which claims "no ontological commitment" (294).

The strange attractor lives in phase space and a phase space portrait abstracts essential information from a system of moving and interdependent parts and makes what James Gleick calls "a flexible road map to the system's possibilities" (134). In phase space, the complete state of knowledge about a dynamical system at a single instant in time collapses to a point. The point is that system at that instant. The information about the system all stored in the point are its variables. At the next instant, however, the system will have changed slightly. If you think of states as a point in space, it makes things easier to watch as they change. A system whose variables are changing continuously up or down, as in a time series, becomes a moving point, like a fly moving round a room. If some combination of variables never occurs, the fly never goes there. If the fly comes round to the same state again and again, the fly traces a loop. By looking at a phase portrait, a person can then think back in his imagination to the system itself. The well known Lorenz attractor (Fig. 1), which looks like a pair of butterfly's wings, describes the rotation of a fluid heated by convection in a cylinder.

\footnotetext{
${ }^{1}$ The mathematical and scientific rationale and implications of strange attractors are documented more fully by James Gleick in Chaos and by Ian Stewart in Does God Play Dice? Here I just present the main ideas.
} 
Fig. 1. Lorenz's Strange Attractor
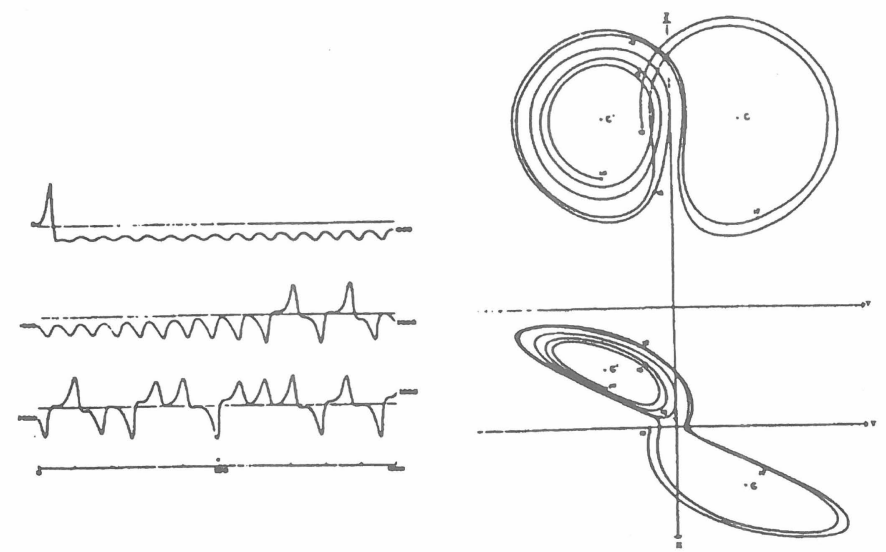

Lorenz's Plots of Convection as Time Series

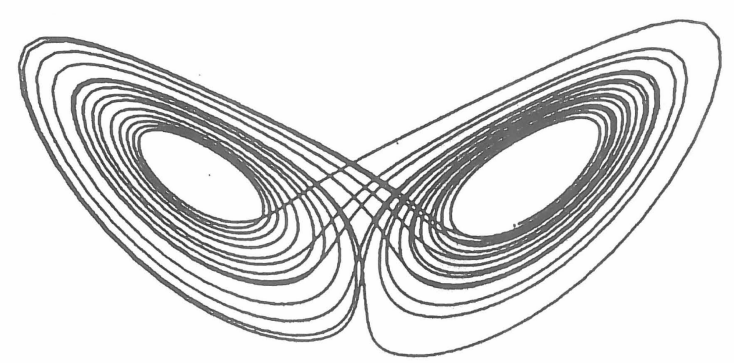

The Lorenz Attractor (Phase Portrait)

Source: Stewart (125)

In terms of The Age of Innocence, the text must be first divided into time intervals against which the incidence of intertextual allusions can be plotted, then converted into a phase portrait. The temporal sequencing of the plot breaks down into three main periods, coinciding with major life events: T1) the three month period spanning Newland's engage- 
ment to May Welland in January of an unspecified year of the early 1870s and ending on the eve of his wedding in April of that same year. Because of the greater frequency of intertextual mentions, this period can be broken down further into three sub-periods as Newland is exposed to new data; T2) his honeymoon in August of that same year followed by some one to one and a half years of his early married life; T3) Newland's reflections some quarter of a century later, that is, round about the turn of the twentieth century. Fig. 2 shows the data. ${ }^{2}$

Fig. 2. RELATIONSHIP: CLUSTERS OF READINGS BY TIME PERIOD

\begin{tabular}{|c|c|c|c|c|c|c|}
\hline \multicolumn{7}{|c|}{$\mathrm{T} 1=$ January early 70 s to April of the same year: 3 months } \\
\hline $\mathrm{T} 1(\mathrm{i})$ & \multicolumn{2}{|c|}{$\begin{array}{l}\text { Walter Pater } \\
\text { J.A. Symonds } \\
\text { Vernon Lee } \\
\text { Ruskin } \\
\text { P.G. Hamerton } \\
\text { Anthropology }\end{array}$} & $\begin{array}{l}\text { W. Irving } \\
\text { Fitz-Greene Halleck } \\
\text { Poet of 'The Culprit Fay' }\end{array}$ & \multicolumn{2}{|c|}{$\begin{array}{l}\text { (Not Ruskin) } \\
\text { Ouida } \\
\text { Thackeray } \\
\text { Dickens } \\
\text { Bulwer } \\
\text { 'Good Words' }\end{array}$} & $\begin{array}{l}\text { Tennyson } \\
\text { - 'Idylls of the King' } \\
\text { - 'Ulysses' } \\
\text { - 'The Lotus Eaters' }\end{array}$ \\
\hline & T1 (ii) & \multicolumn{2}{|c|}{$\begin{array}{l}\text { Bourget } \\
\text { Huysmans } \\
\text { Goncourt Bros }\end{array}$} & T1 (iii) & \multicolumn{2}{|c|}{$\begin{array}{l}\underline{\text { House of Life }} \\
\underline{\text { Middlemarch }} \\
\text { Herbert Spencer } \\
\text { Guy de Maupassant }\end{array}$} \\
\hline \multicolumn{7}{|c|}{ From honeymoon (August) to announcement of pregnancy. 12 to 15 months later. } \\
\hline $\mathrm{T} 2$ & \multicolumn{6}{|c|}{ Michelet's Histories } \\
\hline $\mathrm{T} 3$ & \multicolumn{6}{|c|}{$\begin{array}{c}25 \text { years later } \\
(-)\end{array}$} \\
\hline
\end{tabular}

\footnotetext{
${ }^{2}$ For the sake of brevity, the references selected are solely literary allusions (authors, poets and texts) and those mentioned in clusters rather than as isolated references. To include every cultural or even literary reference would obviously change the final picture, either in degree or kind. I have also omitted stylistic allusions which are unaccompanied by an explicit reference, such as stylistic similarity to Henry James and Jane Austen which arguably belong to the surface level of irony.
} 
The first time interval begins with four clusters which show, from left to right, the perennial reading tastes of Newland Archer; the reading of the older generation in Old New York; Mrs Archer and Janey Archer (the females of the family); and the poetry appreciation classes that Newland is giving to May at the time of their engagement. These can be thought of as representing the initial intellectual conditions of the novel.

The cluster Washington Irving, Fitz-Greene Halleck and "the poet of the Culprit Fay" (Joseph Rodman Drake) provides an opportunity to contrast the present Old New York with its past version. All three are cited as "gentlemen" (Wharton 100). In addition, they are all Americans, all men of letters of the first two decades of the nineteenth century, and wrote as an avocation whilst working for a living. This contrasts with Newland Archer who has a comfortable, if boring, position as a gentleman lawyer and does not participate in culture except as a consumer. Their output of satire, poetry and tales was varied and drew on European sources and traditions, but it was conceived of as being tailored specifically to an American rather than a European readership. They were, in that sense, forward thinking.

The favourite reading of Mrs Archer and her daughter gives an idea of what females were reading at the time. The cluster, which includes the sentimental novelist Ouida, "Good Words," The Marble Faun, Dickens, Thackeray and Bulwer, is notable for its variety of theme and cultural level. The allusion ends with a negative statement that Ruskin was only for "learned people," that is, not for females. If Catherine Mingott, the matriarch, is the base exemplar of cultural illiteracy, May has risen just one rung above Catherine. At the time of their engagement, Newland is giving classes in poetry appreciation to May. The narrator tells us parenthetically, that "She had advanced far enough to join him in ridiculing the Idylls of the King, but not to feel the beauty of Ulysses and the Lotus Eaters" (Wharton 43). Although she is a good social match for Newland and beautiful, the latter is feeling ambivalent about her lack of experience. In his (unspecified) scientific readings, Newland must have encountered the example of the Kentucky Cave Fish, because this is the image he uses of May to criticise her and the society she has grown up in. The fish has lost the functional use of its eyes because it lived permanently in the dark and Newland likens it to the married women of Old New York, who are bred not to see what is going on around them, in the matter of their husbands' sexual peccadilloes, for instance.

The females in Newland's world, his mother, sister, and fiancée, depend on Newland, and on men in general for opinion formation. This is explicit in the case of May, and implicit in his mother and sister, who read an eclectic, but outdated set of authors, about whom they can regurgitate received opinions. Their literature is a constrained "female" one, marked by absence, such as the absence of Ruskin, whom only "learned persons," by definition male, are able to read. The literature is historic and unfashionable, but is not retrospective, that is, the concerns of the writers were not to do with the past, but with the present and the future.

Newland Archer's library, on the other hand, centres on Renaissance art criticism. The males in the group were all British and had "difficult emotional lives," contending with repressed homosexuality, misogyny, unhappy love affairs and unhappy marriages. Their writing is sometimes described as unsystematic, in that it privileges the subjective inspira- 
tion of the writer over attempts at objective representation. This library may be the origin of Bradbury's critical supposition that Newland is "a sensitive, cultured and unhappily married hero, [who] cannot find a use for his intelligence in this rapidly changing American world" (44), although it is a moot point whether his monocultural readings enable his intelligence to develop and whether he does not create his unhappy marriage himself.

There is an odd man out, literally, in the Newland cluster. Vernon Lee, the writer of "Euphorion," was a woman, real name Violet Paget, and a personal friend of Edith Wharton. Round about the turn of the century, she defended equality for women, arguing for economic independence, divorce if necessary, to bring this about. Her concerns were not solely, nor even mainly, aesthetic. This datum may be of interest since Ellen Olenska's (Newland's 'lover') first aim in returning to America from Europe was to obtain a divorce. Newland was sent by the family to dissuade her, even though divorce was not illegal in America at the time. Newland Archer may give the initial impression that he is openminded to the concerns of women, as he criticises the different standards by which men and women are judged in his society. One wonders, therefore, whether Vernon Lee, given her later radical views on women, will make a long term difference to his otherwise introverted obsessions. These provide the four initial literary perspectives which, far from illustrating the supposed cultural homogeneity of Old New York, in fact shows the gaps differences between members of that society, between old and young, between female and male, and between those who look inwards and those who look outwards.

In the next time space, T1 (ii), Newland is sent to convince Ellen Olenska against divorce, although he is reported as being sympathetic to her predicament. At her house in the 'bohemian' quarter, he is struck by differences in her taste in paintings and books and attracted and frightened by her exotic qualities. He comes across three new writers, all French: Paul Bourget, Huysmans and the Goncourt Brothers, and all ahead of their fictional time.

These readings cut across the aesthetic concerns of Newland's way of thinking by introducing some of the social concerns of naturalism, through acquaintance with Emile Zola. In the case of Bourget, naturalism became morality, sometimes to the point of didacticism. His later novels of the first decade of the 20th century aire increasingly didactic theses in support of the church, traditionalism, nationalism, and monarchy.

Even where the subject matter is partly autobiographical, as with Huysmans, or confessional, as with the Goncourt Brothers' Journals, there is evidence of an externally-directed outlook. The best known of Huysmans' novels Against the Grain (1884), relates the experiments in aesthetic decadence undertaken by the bored survivor of a noble line. Together, his novels, semi-autobiographical in content, form a spiritual journey in which the hero tries to find happiness in some kind of spiritual and physical escapism. Each attempt ends on a note of disappointment and revolt until, finally, Huysmans and his hero acknowledge that escapism is both futile and wrong.

These readings seem ironically prophetic. Newland the aesthete, last of a noble line, at first seems to stick to the rules of moral probity outwardly espoused by Old New York. In 
the end, his feelings of frustration and the unreality of his life lead to a desire for escape. Ellen Olenska, perhaps heeding the edifying content of the novels, refuses to break up his marriage, on the grounds that there is no escape.

In this last part of the early phase, T1 (iii), whilst May is away with her family, Newland spends a weekend close to the place where he knows Ellen Olenska is staying. He is becoming more infatuated with Olenska but semi-rationalises his motives for being there in altruistic terms. When he returns home he finds a box of books from his London bookseller containing Guy de Maupassant's Tales, Middlemarch, Herbert Spencer and "The House of Life." He looks through the box and chooses the latter, The House of Life.

In rejecting Middlemarch, he rejects the novelist with an eye for the social survey who promoted the value of 'ordinariness.' He forgets also that 'fallen women' like George Eliot and Ellen Olenska have to survive by compromise rather than idealism. Ellen puts this plainly when she acknowledges the paucity of social options open to her: "I must go where I am invited, or I should be too lonely" (168). Newland rejects also the pessimistic social theorist Herbert Spencer (who coined the epithet 'Survival of the Fittest').

His choice, Rossetti's House of Life is in line with his sentimental, inward-looking mood. It is a sonnet sequence in which detail is subordinated to the intensity of emotion and the evocation of a mood, in this case, the mysteries of physical and spiritual love. His choice is again ironic. In one sonnet, such as number 57, for example, which describes the 'True Woman' the poetic voice of the husband basks in the warmth of mutual harmony and communication with his wife, who freezes out the intruding eyes of a stranger. An image of a mirror, demonstrates only reflected narcissism since the husband can see only himself in the 'true mirror,' his wife ${ }^{3}$.

In the corresponding Old New York scenario, Ellen Olenska's final dismissal of Newland does not just end an 'affair.' She shows Newland who he is through herself. She sees him as a selfish, self-regarding male who thinks and acts as if she belongs to him, when, all along, both she and he were already married to other people. His vision of them being together "in a place where categories like [mistress] . . . don't exist" elicits the rhetorical question "Oh my dear-where is that country? Have you ever been there? . . . I know so many people who've tried to find it; and, believe me, they all got out by mistake at wayside stations . . . and it wasn't at all different from the old world they'd left, but only rather smaller and dingier and more promiscuous" (293).

It becomes increasingly obvious after Newland is married, in T2, that he reads less and less. The most noteworthy feature of this second major time interval is that the increasingly disenchanted Newland avoids discussing poetry with May and has taken up Michelet's histories instead. The genre has changed but the basic instinct hasn't: the inner man and the eyes firmly on the past. Michelet's method was to immerse his own personality in his nar-

\footnotetext{
${ }^{3}$ Bram Dijkstra (143) provides an interesting discussion of this sonnet in the context of 19th century female art representation. The art critics mentioned earlier as being the established reading of Newland Archer are all dealt with in Dijkstra's work in terms of their attitudes towards women, and in the case of Vernon Lee, to men.
} 
rative in an attempt to resurrect the past. His constant theme was to stress man's part in the making of history, a continuous struggle of human freedom against fatality. A key item of interest is that, after several emotional crises, Michelet turned away from Christianity to profess a fervent belief in democratic progress. Since the final time interval, T3, a reflection after some quarter of a century has elapsed, contains no literary allusions at all, one may suppose that Newland has stopped reading altogether. This sudden about-turn is not explained but the single example of Michelet may provide one explanatory mechanism.

Fig. 3 shows the data above converted into an adapted phase portrait which shows flows and influences over time. I cannot hope to emulate the Lorenz attractor in terms of tracing the complexity visually. Instead, I have adapted Ian Stewart's idea of flows to trace short and long-term patterns over the time scale of the novel. ${ }^{4}$

In the first place, we see that a major part of the intertext of The Age of Innocence feeds the interior world of Newland Archer. The constant return in his reading to a European past, to aesthetic criteria, a male point of view and to tortured emotion is represented by the flows within the thick dark oval, itself a limit cycle. His reading feeds the inner man, and hence never leads to concrete action. His apathy towards civic action and his eventual failure as a political representative are indicative of this. Solipsism demonstrates its own failures since its very partialness is unable to perceive its own gaps. The thick black line not only contains sameness, but rejects difference. Hence moral, social, or forward-looking perspectives coming from outside are seen as stopping short of his orbit. Newland verbally espouses the cause of women but there are many examples in the text where he is ambivalent, or even contradictory. We can imagine that the aesthetic criteria of Vernon Lee in his repertoire would fit in with his established ideas but not later, more radical pronouncements about the relative position of real men and women, such as appear in Middlemarch. By rejecting fresh input, Newland effectively excludes the possibility of coming to terms with difference —of viewing his world from a fresh angle, of gaining insights into the situations of other people and of moving towards action.

There is, nonetheless, a strange paradox, which is that Newland Archer survives, not by adaptation or learning, but by default, letting others decide his life for him. He is the chief experiencer of two years of inner turmoil and one voice which half-heartedly criticises the norms of a society which he is on the verge of breaking. Despite this, after a quarter of a century, he manages, like Rip Van Winkle, to wake up in a new society, cheerfully able to discern good in the old ways and good in the new too. Perhaps the fact that he no longer reads accounts for it, or perhaps it is the result of a reorganisation of his world view similar to the change of outlook which Michelet undergoes but which is difficult to explain.

\footnotetext{
${ }^{4}$ For more complete discussion of the theoretical aspects of the phase portrait see Ian Stewart (85-95).
} 


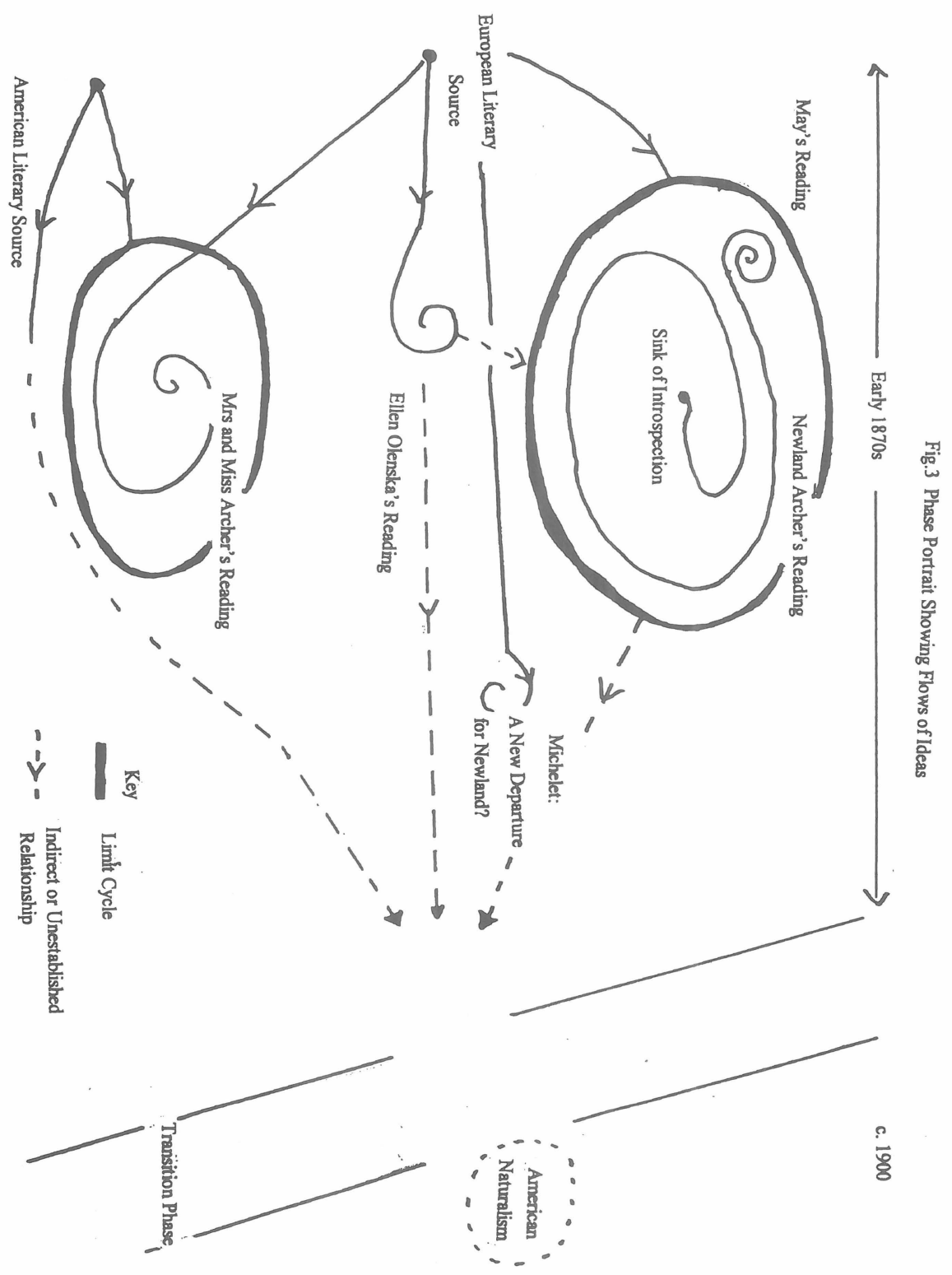

Seen in these individualistic terms, it is difficult to see The Age of Innocence as "in the line of a social novel" (Bradbury 41), nor even as being "somewhat nostalgic" (Cunliffe 267). The text as seen in the phase portrait connects two distinct ideas: one is a critique of inward-looking Romanticism which is seen as going nowhere, and the second is that, despite this, everyone survives (in the emotional sense). The critique of the social scene in 
Old New York is that of Newland Archer effected through the filtering voice of the narrator. The phase portrait, though, shows the extent to which Newland cuts himself off both from his society and from the future by his rejection of 'difference.' What he reads in the early seventies bears a relationship to his attitudes and behaviour in the 1870 s but none to the person and the environment we see in 1900. By 1900, 'Old' New York with its forms and rituals has disappeared, whilst 'New New York' and 'America' (threatening or absent concepts respectively throughout the early seventies) have appeared in the foreground, commercially and technologically alive but bookless. The transition is implied as having been a smooth, rather than a turbulent one, but is nonetheless discontinuous. The temporal discontinuity is implied in the two thick but broken vertical lines (broken because there may be literary cultural links between the two periods but which are not shown in the novel) ${ }^{5}$

Another explanation for the discontinuity is the shift of scope and perspective that Wharton effects in the last chapter. The phase portrait reveals that the representation of one man's consciousness in the early 1870s (in which social considerations actually form only a counterpoint to whatever is going on in his mind), becomes one of New York and America as social entities. Newland's internal world, fuelled by the reading which formed the whole of his emotional horizon, has been significantly scaled down, and the broader social environment expanded.

The other characteristic of The Age Of Innocence is that everyone seems to survive emotionally. May, the blind Kentucky Cave Fish, is, in the end, perfectly able to lead the blind Newland to where she wants him to go, in spite of the Tennyson classes. Ellen Olenska imposes self-restraint, perhaps as a result of reading Bourget and Huysmans. She does not spend her life being maintained in the visionary world that Newland offers her, but, by renouncing self-gratification and selfish passion, ends up in Paris, independent and, one assumes, able to support herself. This strategy works for her, but it is to be noted that selfrestraint is not posited as a long-term collective strategy linking two societies, hence there is no link to the future.

The novel is neither pessimistic (although this does not necessarily imply that progress has been made), nor is it a closed text. It does not fit comfortably into any of the critical categories invented for it, although, at the same time, it is difficult not to concur in part with what critics say. Ian Stewart says: "There is a theory that history moves in cycles-but it is like a spiral staircase. When the course of human events comes full circle it does so on a new level" (xi). This, I think, is what the Age of Innocence is, the spiralling between the level of the 1870s and that of 1900, the latter being open-ended.

\footnotetext{
${ }^{5}$ Two examples of indirect links might be the development of American naturalism out of French naturalism, with sources going back beyond Bourget, the Goncourt Brothers and Huysmans, or the example of Irving, Halleck and the poet of 'The Culprit Fay' who are represented as the approved reading matter of an older generation, and therefore out of date. Together, though, they conceived of the possibility of a home-grown American literature rather than an imported European one, even though they did not live long enough to see it.
} 
To return to the question of irony with which I opened this particular discussion, if the intertext constitutes a thread of irony different from the surface irony, can it be said to work additively, that is, does it support the message provided by the unreliable narrator, or does it move contrariwise, admitting the possibility of a new reading, a different set of voices from the narrator's, a reorganisation of the text into something new?

The difference between the left and right-handed DNA molecules may be of some application in this context. DNA is described as a codebook. A 'reader molecule' reads the code and transmits information to the cells, indicating which substances are to be built. In some $10 \%$ of cases, however, the DNA reading coincides with a change of form of the DNA molecule from the usual right to the left. When this occurs, an 'editor molecule' which is highly attracted to the left-handed DNA, jumps over and alters the coding of the message as it is reading it. DNA, therefore, is not passive, but active, there being more than one way of reading DNA, the usual way and in the edited form.

I cautiously suggest that the literary allusions, in this case, effect a similar transformation, enabling the aroused editing molecule (the reader) to access different readings of people and events. Surface irony performs in the usual way, directing the reader to a mocking view of the rituals and characters of Old New York. This is directed particularly at the older generation and the hypocritical males, although Newland is not exempt from the critical voice. The intertextual allusions activate an alternative path of investigation, in which Newland's baroque complicity in his own blindness is highlighted. This strand of the reading disapproves of Newland. By the last chapter, in 1900, all irony, severe and gently mocking, has faded and the novel turns out to have been a case of 'much ado about nothing.'

My final verdict, that the text's meaning straddles many critical positions without being of any one of them, forces the reader to abandon her habitual position and to sit rather unsteadily on a 'fence.' This indeterminacy can be read as a challenge. If a novel about the past is useful merely to play around with nostalgia, then it is not useful at all since a novel is not a problem of the past but of today. There are still plenty of Newland Archers and Old New Yorks around.

\section{WORKS CITED}

Bradbury, Malcolm. The Modern American Novel. 2nd ed. Oxford: OUP, 1992.

Cunliffe, Marcus. The Literature of the United States. 4th ed. Harmondsworth: Penguin, 1986.

Dijkstra, Bram. Idols of Perversity: Fantasies of Feminine Evil in Fin-de-Siècle Culture. New York and Oxford: OUP, 1986.

Gleick, James. Chaos: Making a New Science. Harmondsworth: Penguin, 1987.

Lass, Roger. Historical Linguistics and Language Change. Cambridge Studies in Linguistics 81. Cambridge: Cambridge UP, 1997.

Stewart, Ian. Does God Play Dice? 2nd ed. Harmondsworth: Penguin, 1997.

Wharton, Edith. The Age of Innocence. (1920) Harmondsworth: Penguin, 1996. 
